\title{
Azospirillum brasilense inoculation methods in corn and sorghum ${ }^{1}$
}

\author{
Agner de Freitas Andrade 2 , Tiago Zoz², \\ André Zoz ${ }^{2}$, Carlos Eduardo da Silva Oliveira ${ }^{2}$, Travis Wilson Witt ${ }^{3}$
}

\section{ABSTRACT}

The Azospirillum brasilense inoculation is usually carried out via seed. However, this bacterium presents passive penetration in the plant, what makes it possible to inoculate the crops using other methods. This study aimed to evaluate the influence of $A$. brasilense inoculation methods on the emergence and initial growth of corn and sorghum, under greenhouse conditions. A randomized block design, with four replications, in a $4 \times 2$ factorial scheme, was used. The first factor consisted of a control treatment (without inoculation) and three inoculation methods: via seed, via sowing furrow and via leaf spray. The second factor was composed by two hybrids of corn and two of sorghum. The application of $A$. brasilense to the seed can reduce the emergence percentage and the emergence speed index of corn seedlings, depending on the genotype, but its application does not influence the initial growth of the plants. The $A$. brasilense inoculation via seed and via sowing furrow can reduce the emergence and increase the mean emergence time of sorghum seedlings, depending on the genotype. The $A$. brasilense inoculation via seed results in an increase in the dry mass of the root system of sorghum plants.

KEY-WORDS: Zea mays, Sorghum bicolor, diazotrophic bacteria.

\section{INTRODUCTION}

Nitrogen fertilization in non-leguminous crops, such as corn (Zea mays) and sorghum (Sorghum bicolor L.), is one of the costliest factors in the production process (Nunes et al. 2015). There is a great interest in the development of alternatives for the supply of nitrogen during the production of these crops, in order to reduce production costs. The biological fixation of atmospheric nitrogen by diazotrophic bacteria is one of the most promising

\begin{abstract}
RESUMO
Modos de inoculação de Azospirillum brasilense em milho e sorgo

A inoculação de Azospirillum brasilense, normalmente, é realizada via semente. Entretanto, essa bactéria apresenta penetração passiva na planta, o que torna possível a inoculação das culturas utilizando-se outros métodos. Objetivou-se avaliar a influência de modos de inoculação de $A$. brasilense na emergência e crescimento inicial de milho e sorgo, sob cultivo protegido. Utilizou-se delineamento de blocos ao acaso, com quatro repetições, em esquema fatorial $4 \times 2$. O primeiro fator foi composto por um tratamento controle (sem inoculação) e três modos de inoculação: via semente, via sulco de semeadura e via pulverização foliar. O segundo fator foi composto por dois híbridos de milho e dois de sorgo. A aplicação de A. brasilense à semente pode reduzir a porcentagem de emergência e o índice de velocidade de emergência de plântulas de milho, dependendo do genótipo, mas sua aplicação não influencia no crescimento inicial das plantas. A inoculação de $A$. brasilense via semente e via sulco pode reduzir a porcentagem de emergência e aumentar o tempo médio de emergência de plântulas de sorgo, dependendo do genótipo. A inoculação de $A$. brasilense via semente resulta em aumento de massa seca do sistema radicular de plantas de sorgo.
\end{abstract}

PALAVRAS-CHAVE: Zea mays, Sorghum bicolor, bactérias diazotróficas.

alternatives. Among their species, Azospirillum is the most studied one (Morais et al. 2015) and, currently, Azospirillum brasilense has gained more prominence and has been used commercially (Kappes et al. 2013).

In addition to the nitrogen fixation, other beneficial effects of these bacteria have already been identified, such as stimulating the root system growth (Bashan \& Bashan 2005) and synthesizing phytohormones (Cassán et al. 2011). Despite the many positive effects already highlighted, the

1. Received: May 17, 2018. Accepted: Oct. 04, 2018. Published: Jun. 03, 2019. DOI: 10.1590/1983-40632019v4953027.

2. Universidade Estadual de Mato Grosso do Sul, Departmento de Agronomia, Cassilândia, MS, Brasil.

E-mail/ORCID: agner_freitas@hotmail.com/0000-0001-6809-0944,zoz@uems.br/0000-0003-2991-5485, andre_zoz@hotmail.com/0000-0002-9879-9871, carllos_eduard@hotmail.com/0000-0002-3894-9559.

3. Eastern New Mexico University, Department of Agriculture, Food Science and Kinesiology, Portales, NM, USA. E-mail/ORCID: travis.witt@enmu.edu/0000-0003-4501-4230. 
inoculation method of the bacteria in corn and sorghum is not yet fully understood.

In Gramineae, diazotrophic endophytic bacteria have a passive penetration into the plant, accessing the interior through wounds, roots, root cap and stoma sites in the leaves, spreading through the root tissues via apoplast, colonizing the intercellular spaces of the cells of the hypodermis, root cortex and aerenchyma wall (Olivares et al. 1997, James \& Olivares 1998).

Most studies with Azospirilum spp. in corn have been carried out with inoculation via seed. Some showed positive results (Novakowiski et al. 2011, Guimarães et al. 2013, Costa et al. 2015). However, others showed no positive effects on grain yield (Vogt et al. 2014, Pandolfo et al. 2015, Sangoi et al. 2015, Rockenbach et al. 2017). Some studies indicate positive results of corn seeds inoculated with $A$. brasilense when associated with the use of nitrogen fertilizers (Araújo et al. 2014, Moraes et al. 2017, Szilagyi-Zecchin et al. 2017). Finally, some studies show that the use of $A$. brasilense do not influence the corn yield, independently of the use of nitrogen fertilizer (Repke et al. 2013, Vogt et al. 2014, Pandolfo et al. 2015, Sangoi et al. 2015).

Pereira et al. (2015) verified that the inoculation, independently of being via seed or sowing furrow, do not influence the chlorophyll index of corn plants. The same authors observed a higher nitrogen content with the inoculation via sowing furrow only in two corn genotypes (2B707 and the synthetic hybrid V2). Due to the ability of the bacteria to colonize the internal tissues of plants (Costa et al. 2015), the $A$. brasilense foliar application in corn was also evaluated, but no positive effects were observed on grain yield (Ciciliato \& Casimiro 2015).

Despite the different forms of inoculation highlighted in these studies, none of them has compared the efficiency of inoculations via seed, soil and leaf. Thus, this study was performed based on the hypothesis that, among the three $A$. brasilense inoculation methods (seed, soil or leaf), one of them presents a significantly higher efficiency. Therefore, it aimed to evaluate the influence of $A$. brasilense inoculation methods on corn and sorghum plants.

\section{MATERIAL AND METHODS}

Two experiments were carried out under greenhouse conditions at the Universidade Estadual de Mato Grosso do Sul, in Cassilândia, Mato Grosso do Sul state, Brazil (19 $05^{\circ} \mathrm{S}, 51^{\circ} 48^{\prime} \mathrm{W}$ and average altitude of $470 \mathrm{~m}$ ), from March to April 2016.

Each experimental unit was composed of one pot $\left(5.0 \mathrm{dm}^{3}\right)$ filled with $6.0 \mathrm{~kg}$ of dry soil collected in the $0-20 \mathrm{~cm}$ depth layer and sifted in a fine mesh sieve and not sterilized. The soil is classified as an Arenic Entisol (USA 2010) (95 $\mathrm{g} \mathrm{kg}^{-1}$ of clay, $50 \mathrm{~g} \mathrm{~kg}^{-1}$ of silt and $855 \mathrm{~g} \mathrm{~kg}^{-1}$ of sand). The soil chemical characteristics before the implantation of the experiment are presented in Table 1.

The experimental design used for the two experiments was a randomized block design, with four replications, in a $4 \times 2$ factorial scheme. The first factor was composed of three A. brasilense inoculation methods (via seed, via sowing furrow and via foliar spray) and one control (without inoculation). The second factor consisted of two corn hybrids [NS 92 (medium simple hybrid) and Impacto (medium simple hybrid)] and two sorghum hybrids [DOW 1 G282 (early hybrid) and AG1090 (early hybrid)].

Ten seeds of corn and sorghum were sown per pot, and, after the stabilization of the emergence, thinning was done, leaving only one plant per pot. For inoculation, the commercial product NITRO1000 Gramineas, liquid inoculant with AbV5 and AbV6 strains of $A$. brasilense, at the concentration of $2.0 \mathrm{x}$ $10^{8}$ viable cells per $\mathrm{mL}$, was used.

For the seed inoculation, the used inoculant dose was $100 \mathrm{~mL}$ for 60,000 corn seeds $(333,333$ cells per seed) and $100 \mathrm{~mL}$ for 180,000 sorghum

Table 1. Soil chemical traits in the $0-20 \mathrm{~cm}$ layer, before the implantation of the experiments.

\begin{tabular}{|c|c|c|c|c|c|c|c|c|c|c|c|}
\hline \multirow{2}{*}{$\mathrm{pH}$} & $\mathrm{P}_{\text {resine }}$ & $\mathrm{OM}$ & $\mathrm{K}$ & $\mathrm{Ca}$ & $\mathrm{Mg}$ & $\mathrm{Al}$ & $\mathrm{Al}+\mathrm{H}$ & SB & $\mathrm{CEC}$ & $\mathrm{V}(\%)$ & \multirow{2}{*}{$\begin{array}{c}{\mathrm{S}-\mathrm{SO}_{4}}^{\mathrm{mg} \mathrm{dm}}{ }^{-3} \\
\end{array}$} \\
\hline & $\mathrm{mg} \mathrm{dm}^{-3}$ & $\mathrm{~g} \mathrm{dm}^{-3}$ & \multicolumn{8}{|c|}{$-\mathrm{mmol}_{\mathrm{c}} \mathrm{dm}^{-3}$} & \\
\hline 5.2 & 2.0 & 14.0 & 1.7 & 10.0 & 7.0 & 0.0 & 22.0 & 18.7 & 40.7 & 46 & 2.0 \\
\hline \multicolumn{2}{|c|}{$\mathrm{m}$} & \multicolumn{2}{|c|}{$\mathrm{B}$} & \multicolumn{2}{|c|}{$\mathrm{Cu}$} & & & \multicolumn{2}{|c|}{$\mathrm{Mn}$} & \multicolumn{2}{|c|}{$\mathrm{Zn}$} \\
\hline \multicolumn{2}{|c|}{$\%$} & \multicolumn{10}{|c|}{$\mathrm{mg} \mathrm{dm}^{-3}$} \\
\hline \multicolumn{2}{|c|}{0} & \multicolumn{2}{|c|}{0.08} & \multicolumn{2}{|c|}{0.60} & & & \multicolumn{2}{|c|}{5.70} & \multicolumn{2}{|c|}{0.30} \\
\hline
\end{tabular}


seeds $(111,111$ cells per seed). For the inoculation via sowing furrow, ten holes were opened in each pot, one seed was deposited in each hole, the inoculant was added with a micropipette and the hole was closed. In each groove, an amount of inoculant equivalent to the supply of 333,333 and 111,111 cells per well for corn and sorghum, respectively, was added. The inoculant doses applied through the hole are equivalent to $100 \mathrm{~mL}$ per hectare for corn and sorghum.

For the foliar spraying, the doses of 333,333 and 111,111 cells per plant of corn and sorghum, respectively (considering the population of 60,000 plants $\mathrm{ha}^{-1}$ and 180,000 plants $\mathrm{ha}^{-1}$ for corn and sorghum, respectively), were applied, corresponding to $100 \mathrm{~mL}$ of the commercial inoculant per hectare. Spraying was performed at 9 days after the emergence (DAE). The spray volume used was equivalent to $165 \mathrm{~L} \mathrm{ha}^{-1}$. A backpack sprayer with conical tip was used. Spraying was performed late in the afternoon, in order to avoid losses by evaporation.

At 15 DAE, fertilization was performed with $150 \mathrm{mg} \mathrm{dm}^{-3}$ of $\mathrm{K}$ (potassium chloride) and $300 \mathrm{mg} \mathrm{dm}^{-3}$ of P (simple superphosphate). The fertilizer sources were diluted in water and then applied to the pot. The water retention capacity of the soil was estimated according to Gonçalves Junior et al. (2000). Daily, two pots of each block were randomly weighed and, based on the water retention capacity in the soil and the pots weight, the amount of water to be daily applied per pot was estimated to maintain the soil with $75 \%$ of the water retention capacity. Phytosanitary treatments were carried out according to the technical recommendations for the crop.

The following evaluations were carried out: emergence speed index: obtained by daily counting the number of emerged seedlings, until the emergence stabilization (Maguire 1962); mean emergence time: estimated by daily counting the number of emerged seedlings until the emergence stabilization (Edmond \& Drapala 1958); seedling emergence (\%): measured by counting the seedlings emerged after the stabilization of the stand.

At 43 and 53 DAE, the following evaluations were carried out on corn and sorghum crops, respectively: stem diameter $(\mathrm{mm})$ : obtained with a digital caliper in the first internode; plant height $(\mathrm{cm})$ : distance from the ground level to the apex of the plant canopy; number of expanded leaves per plant: estimated by counting the total number of leaves in each plant; relative chlorophyll index: evaluated with a portable meter (CCM-200, Apogee Instruments), being carried out four measures in each plant, in the middle third of the leaves.

Immediately after the evaluation of stem diameter, plant height, number of expanded leaves per plant and relative chlorophyll index, the plants were cut close to the soil and sectioned into leaves and stem. The leaves, stems and roots were placed in a forced circulation oven at $65^{\circ} \mathrm{C}$, for $72 \mathrm{~h}$, to obtain the leaf dry mass, stem dry mass, root system dry mass, shoot dry mass (sum of the stem dry mass and leaf dry mass), total dry mass (sum of the shoot dry mass and root system dry mass) and leaf area $\left(\mathrm{dm}^{2}\right.$ plant $\left.^{-1}\right)$, which was estimated according to Benincasa (2003).

The data of both experiments were tested for normality and homoscedasticity analysis and later transformed into $\sqrt{\mathrm{x}}$. After the data transformation, analysis of variance and mean squares were tested by the $\mathrm{F}$ test at $5 \%$ of probability. The means related to the inoculation were compared by the t-test (LSD). The averages for corn and sorghum hybrids were compared by the F test at $5 \%$ of probability.

\section{RESULTS AND DISCUSSION}

An interaction between the $A$. brasilense inoculation methods and corn hybrids was observed only for seedling emergence and emergence speed index (Table 2). There was no difference between the A. brasilense inoculation methods and the control for the Impacto hybrid (Table 2). For the NS 92 hybrid, it was verified that the $A$. brasilense inoculation via seed resulted in a lower emergence and emergence speed index, when compared to the other inoculation methods and the treatment without inoculation.

Table 2. Emergence and emergence speed index of seedlings of the Impacto and NS 92 corn hybrids, using different Azospirillum brasilense inoculation methods.

\begin{tabular}{lcccc}
\hline \multirow{2}{*}{ Treatment } & \multicolumn{2}{c}{ Emergence (\%) } & \multicolumn{2}{c}{ Emergence speed index } \\
\cline { 2 - 5 } \multicolumn{1}{c}{ Impacto } & NS 92 & Impacto & NS 92 \\
\hline Without inoculation & $97.5 \mathrm{aA} *$ & $97.5 \mathrm{aA}$ & $3.83 \mathrm{aA}$ & $3.57 \mathrm{aA}$ \\
Seed & $100.0 \mathrm{aA}$ & $65.0 \mathrm{bB}$ & $4.13 \mathrm{aA}$ & $2.29 \mathrm{bB}$ \\
Sowing furrow & $100.0 \mathrm{aA}$ & $90.0 \mathrm{aA}$ & $4.33 \mathrm{aA}$ & $3.44 \mathrm{aB}$ \\
Foliar spray & $100.0 \mathrm{aA}$ & $90.0 \mathrm{aA}$ & $4.54 \mathrm{aA}$ & $3.67 \mathrm{aB}$ \\
\hline Average & 99.38 & 85.63 & 4.21 & 3.24 \\
\hline CV $(\%)$ & \multicolumn{2}{c}{2.61} & \multicolumn{2}{c}{3.18}
\end{tabular}

* Distinct lowercase letters in the column indicate a significant difference among the $A$. brasilense inoculation methods by the t-test (LSD) at $5 \%$ of probability, while distinct uppercase letters in the row indicate a significant difference between the corn hybrids by the $\mathrm{F}$ test at $5 \%$ of probability. 
Similar results were observed in a study by Pereira et al. (2015), where the inoculation via seeds reduced the emergence and emergence speed index for corn. Souza et al. (2014), evaluating the physiological quality of sweet corn seeds inoculated with $A$. brasilense at different periods and dilutions in water, verified that, as the time between inoculation and sowing increased, a reduction was observed in the first germination count, emergence speed index and root system dry mass.

In the comparison between hybrids, it should be noted that the seeds of both hybrids presented a similar vigor. The results of emergence and emergence speed index were similar among the hybrids for the control treatment. For the inoculation via seed, a higher emergence percentage was observed for the Impacto hybrid (Table 2). For the emergence speed index, it was found that Impact had an average approximately $80 \%, 26 \%$ and $24 \%$ higher than NS 92 for inoculation via seed, sowing furrow and foliar spray, respectively (Table 2). There was no difference between the hybrids for the seedling emergence and emergence speed index in the treatment without inoculation (Table 2).

The number of expanded leaves, plant height, leaf area, stem diameter and relative chlorophyll index were not influenced by the A. brasilense inoculation methods (Table 3 ). It was verified that NS 92 presented a leaf area around $37 \%$ greater than Impacto (Table 3).

In a study by Kappes et al. (2013), the inoculation of seeds with $A$. brasilense did not affect the stem diameter of corn plants. Pereira et al. (2015) verified that the $A$. brasilense inoculation does not influence the chlorophyll index in corn.
A possible cause for the absence of influence of the inoculation on the relative chlorophyll index may be the phenological stage at which the plants were evaluated. In a study by Quadros et al. (2014), the seeds of three corn genotypes (P32R48, SHS 5050 and AS 1575) inoculated with A. brasilense influenced the chlorophyll content in two of the genotypes (P32R48 and SHS 5050) only after the V17 stage and, for the other genotype, there was an influence of inoculation in the V6 stage, and again after the R1 stage. That is, the influence was verified on the chlorophyll relative index when the plants were in more advanced stages of development than in the present study.

The stem diameter and relative chlorophyll index were approximately $13 \%$ and $53 \%$ higher for Impact than for NS 92, respectively (Table 3). No difference was observed between the hybrids for the number of expanded leaves and plant height (Table 3).

The root system dry mass, leaf dry mass and stem dry mass were not influenced by the A. brasilense inoculation methods (Table 4). No difference was observed between the hybrids for root system dry mass and stem dry mass (Table 4). The leaf dry mass was around $39 \%$ higher for NS 92 than for Impacto (Table 4).

No influence of the $A$. brasilense inoculation methods on shoot dry mass and total dry mass (Table 4) was observed. For NS 92, the shoot dry mass was around $23 \%$ higher than for Impacto (Table 4). There was no difference between the hybrids for total dry mass (Table 4).

The inoculation methods did not influence the initial growth of corn plants. In a study that aimed

Table 3. Number of expanded leaves (NEL), plant height (PH), leaf area (LA), stem diameter (SD) and relative chlorophyll index (RCI) of corn plants, with different Azospirillum brasilense inoculation methods.

\begin{tabular}{lccccc}
\hline \multirow{2}{*}{ Treatment } & NEL & PH & LA & SD & RCI \\
\cline { 2 - 6 } & $\mathrm{n}^{\circ}$ plant $^{-1}$ & $\mathrm{~cm}$ & $\mathrm{dm}^{2} \mathrm{plant}^{-1}$ & $\mathrm{~mm}$ & - \\
\hline Without inoculation & $7.88 \mathrm{a}^{*}$ & $82.98 \mathrm{a}$ & $15.12 \mathrm{a}$ & $13.06 \mathrm{a}$ & $10.51 \mathrm{a}$ \\
Seed & $8.00 \mathrm{a}$ & $87.40 \mathrm{a}$ & $15.29 \mathrm{a}$ & $12.44 \mathrm{a}$ & $10.00 \mathrm{a}$ \\
Sowing furrow & $7.88 \mathrm{a}$ & $83.28 \mathrm{a}$ & $14.71 \mathrm{a}$ & $12.09 \mathrm{a}$ & $7.60 \mathrm{a}$ \\
Foliar spray & $8.13 \mathrm{a}$ & $82.20 \mathrm{a}$ & $14.13 \mathrm{a}$ & $12.95 \mathrm{a}$ & $11.03 \mathrm{a}$ \\
\hline \multicolumn{1}{c}{ Hybrid } & & & & \\
Impacto & $7.75 \mathrm{a}$ & $81.77 \mathrm{a}$ & $12.48 \mathrm{~b}$ & $13.41 \mathrm{a}$ & $11.82 \mathrm{a}$ \\
NS 92 & $8.19 \mathrm{a}$ & $86.16 \mathrm{a}$ & $17.15 \mathrm{a}$ & $11.86 \mathrm{~b}$ & $7.75 \mathrm{~b}$ \\
\hline Average & 7.97 & 83.96 & 14.81 & 12.63 & 9.78 \\
\hline CV $(\%)$ & 2.06 & 2.07 & 4.44 & 1.79 & 8.12 \\
\hline * Means followed by different lowercase letters in the column differ from each other by the t-test (LSD) at 5\% of significance. &
\end{tabular}


Table 4. Leaf dry mass (LDM), stem dry mass (SDM), shoot dry mass (SHDM), root system dry mass (RSDM) and total dry mass (TDM) of corn plants, with different Azospirillum brasilense inoculation methods.

\begin{tabular}{|c|c|c|c|c|c|}
\hline \multirow{2}{*}{ Treatment } & LDM & SDM & SHDM & RSDM & TDM \\
\hline & \multicolumn{5}{|c|}{ g plant $t^{-1}$} \\
\hline Without inoculation & $5.28 \mathrm{a}^{*}$ & $4.27 \mathrm{a}$ & $9.55 \mathrm{a}$ & $14.46 \mathrm{a}$ & $24.01 \mathrm{a}$ \\
\hline Seed & $5.29 \mathrm{a}$ & $4.11 \mathrm{a}$ & $9.40 \mathrm{a}$ & $13.69 \mathrm{a}$ & $23.09 \mathrm{a}$ \\
\hline Sowing furrow & $5.14 \mathrm{a}$ & $4.38 \mathrm{a}$ & $9.53 \mathrm{a}$ & $11.21 \mathrm{a}$ & $20.74 \mathrm{a}$ \\
\hline Foliar spray & $5.12 \mathrm{a}$ & $4.11 \mathrm{a}$ & $9.23 \mathrm{a}$ & $17.11 \mathrm{a}$ & $26.33 \mathrm{a}$ \\
\hline \multicolumn{6}{|l|}{ Hybrid } \\
\hline Impacto & $4.36 \mathrm{~b}$ & $4.11 \mathrm{a}$ & $8.47 \mathrm{~b}$ & $12.65 \mathrm{a}$ & $21.12 \mathrm{a}$ \\
\hline NS 92 & $6.05 \mathrm{a}$ & $4.33 \mathrm{a}$ & $10.38 \mathrm{a}$ & $15.59 \mathrm{a}$ & $25.97 \mathrm{a}$ \\
\hline Mean & 5.21 & 4.22 & 9.43 & 14.12 & 23.54 \\
\hline $\mathrm{CV}(\%)$ & 5.40 & 6.27 & 5.66 & 11.34 & 8.08 \\
\hline
\end{tabular}

to evaluate the effects of fertilization with mineral nitrogen and inoculation with $A$. brasilense via seed on the morphophysiological traits of corn plants at 40 days after sowing, Morais et al. (2015) only verified effects of the fertilization with mineral nitrogen on morphophysiological traits.

In a study aimed at evaluating the effect of A. brasilense inoculated via seed in association with nitrogen doses on the development of corn plants, Repke et al. (2013) concluded that the inoculation with or without nitrogen doses does not interfere with the development of plants and on corn yield. Evaluating the inoculation of $A$. brasilense via seed and foliar spray in corn, Ciciliato \& Casimiro (2015) verified that there was no influence of the bacteria on the plants.

Some results found in the literature highlight that, to obtain positive results, it is necessary to associate Azospirillum with nitrogen fertilization, because only the bacterium will not respond in a positive way (Hungria 2011, Skonieski et al. 2017, Souza et al. 2019). In addition to the biological fixation of nitrogen, $A$. brasilense produces some phytohormones that contribute to the growth of plants; however, maybe only phytohormones are not enough for a positive response to occur in the inoculated plant.

In part, the lack of response of $A$. brazilense inoculation in corn may be explained because the efficiency of the bacterium varies according to the genotype of the host plant (Reis Junior et al. 2008, Marini et al. 2015, Pereira et al. 2015).

Pereira et al. (2015), evaluating four corn genotypes (AG 7098, 2B707 and two synthetic hybrids - V2 and V4), verified that, for the root dry mass, the $A$. brasilense inoculation via seed and sowing furrow had a positive effect on two genotypes (AG 7098 and 2B707), a negative effect on one genotype (V2) and did not influence the root dry mass in the other genotype. For the shoot dry matter, the same authors verified that the $A$. brasilense inoculation via seed favored only one genotype (V2), whereas, for the other three genotypes, no inoculation influence was observed.

Regarding the inoculation methods, Pereira et al. (2015) found that the four evaluated corn genotypes showed a variable response to the nitrogen content in the leaves for the inoculation via seed and via sowing furrow, i.e., the inoculation via seed favored some genotypes, whereas the sowing furrow inoculation favored others.

Due to the negative effect on seedling emergence and the lack of corn response, regardless of the inoculation method, the A. brasilense inoculation is not recommended for corn. The fact that some genotypes respond positively, while others do not, makes its use unfeasible for now.

An interaction between the $A$. brasilense inoculation methods and sorghum hybrids was verified for the percentage of seedling emergence and mean emergence time (Table 5). A similar vigor was observed among seeds of the two sorghum hybrids, as evidenced by the fact that there was no difference between the hybrids in the control treatment for the emergence and mean emergence time.

For the AG 1090 hybrid, the furrow inoculation reduced the mean emergence time, when compared to the control and seed inoculation (Table 5). The A. brasilense inoculation in the seed and sowing furrow reduced the seedling emergence percentage 
of DOW 1 G282 and AG1090, respectively, when compared to the other treatments (Table 5).

Similar results were found by Pereira et al. (2015), when evaluating corn genotypes inoculated with $A$. brasilense via seed, in which a lower emergence percentage was noticed when the seeds were inoculated. Souza et al. (2014) observed a reduction in the physiological potential of sweet corn seeds as time elapsed between the $A$. brasilense inoculation and sowing, reducing the first germination count, emergence speed index and root dry mass.

For the emergence speed index, plant height, stem diameter, relative chlorophyll index and number of expanded leaves, there was no difference between the $A$. brasilense inoculation methods and sorghum hybrids (Table 6).

The relative chlorophyll index may not have differed due to the phenological stage in which the plants were evaluated. In a study evaluating A. brasilense inoculation via seeds in corn genotypes (P32R48, SHS 5050 and AS 1575), Quadros et al. (2014) verified an increase in the chlorophyll content in two genotypes (P32R48 and SHS 5050) only after the V17 stage, and for another genotype (AS 1575) in the V6 stage and after the R1 stage. There are discordant reports about the influence of A. brasilense on the chlorophyll content, emphasizing that, in studies where there was a difference in the chlorophyll content (Quadros et al. 2014, Pereira et al. 2015, Souza et al. 2019), the evaluations were carried out at more advanced stages than in the present study.

For the leaf area, leaf dry mass, stem dry mass, shoot dry mass and total dry mass, no differences were observed between the inoculation methods and sorghum hybrids (Table 7). Dartora et al. (2013) verified that the inoculation with $A$. brasilense does not influence the plant height, leaf area and shoot dry mass in corn.

The $A$. brasilense inoculation via seed promoted an increase in the root system dry mass, when compared to the other treatments (Table 7). Similar results were found by Costa et al. (2015), who verified a higher dry mass of the root system

Table 5. Emergence and mean emergence time of sorghum seedlings (1G 282 and IG 1090 hybrids), with different Azospirillum brasilense inoculation methods.

\begin{tabular}{lcccc}
\hline \multirow{2}{*}{ Treatment } & Emergence (\%) & \multicolumn{3}{c}{ Mean emergence time (days) } \\
\cline { 2 - 5 } & $1 \mathrm{G} 282$ & AG 1090 & $1 \mathrm{G} \mathrm{282}$ & AG 1090 \\
\hline Without inoculation & $92.5 \mathrm{aA} *$ & $92.5 \mathrm{aA}$ & $3.45 \mathrm{aA}$ & $3.86 \mathrm{aA}$ \\
Seed & $70.0 \mathrm{bB}$ & $90.0 \mathrm{aA}$ & $3.64 \mathrm{aA}$ & $3.62 \mathrm{abA}$ \\
Sowing furrow & $87.5 \mathrm{aA}$ & $70.5 \mathrm{bB}$ & $3.81 \mathrm{aA}$ & $3.07 \mathrm{cB}$ \\
Foliar spray & $87.5 \mathrm{aA}$ & $87.5 \mathrm{aA}$ & $3.77 \mathrm{aA}$ & $3.41 \mathrm{bcA}$ \\
\hline Mean & 82.37 & 85.12 & 3.66 & 4.22 \\
\hline $\mathrm{CV}(\%)$ & & 6.94 & & \\
\hline
\end{tabular}

* Distinct lowercase letters in the column indicate a significant difference among the $A$. brasilense inoculation methods by the t-test (LSD) at $5 \%$ of probability, while distinct uppercase letters in the row indicate a significant difference between the sorghum hybrids by the $\mathrm{F}$ test at $5 \%$ of probability.

Table 6. Emergence speed index (ESI), plant height (PH), stem diameter (SD), relative chlorophyll index (RCI) and number of expanded leaves (NEL) of sorghum plants, with different Azospirillum brasilense inoculation methods.

\begin{tabular}{|c|c|c|c|c|c|}
\hline \multirow{2}{*}{ Treatment } & \multirow{2}{*}{ ESI } & $\mathrm{PH}$ & SD & \multirow{2}{*}{$\mathrm{RCI}$} & NEL \\
\hline & & $\mathrm{cm}$ & $\mathrm{mm}$ & & $\mathrm{n}^{\mathrm{o}}$ plant $^{-1}$ \\
\hline Without inoculation & $2.56 \mathrm{a}^{*}$ & $52.69 \mathrm{a}$ & $8.80 \mathrm{a}$ & $15.48 \mathrm{a}$ & $4.75 \mathrm{a}$ \\
\hline Seed & $2.21 \mathrm{a}$ & $59.50 \mathrm{a}$ & $9.61 \mathrm{a}$ & $14.63 \mathrm{a}$ & $5.13 \mathrm{a}$ \\
\hline Sowing furrow & $2.65 \mathrm{a}$ & $63.38 \mathrm{a}$ & $9.88 \mathrm{a}$ & $16.14 \mathrm{a}$ & $4.75 \mathrm{a}$ \\
\hline Foliar spray & $2.48 \mathrm{a}$ & $59.25 \mathrm{a}$ & $9.54 \mathrm{a}$ & $18.43 \mathrm{a}$ & $5.25 \mathrm{a}$ \\
\hline \multicolumn{6}{|l|}{ Hybrid } \\
\hline $1 \mathrm{G} 282$ & $2.59 \mathrm{a}$ & $57.97 \mathrm{a}$ & $9.04 \mathrm{a}$ & $16.83 \mathrm{a}$ & $4.88 \mathrm{a}$ \\
\hline AG 1090 & $2.53 \mathrm{a}$ & $59.44 \mathrm{a}$ & $9.87 \mathrm{a}$ & $15.52 \mathrm{a}$ & $5.06 \mathrm{a}$ \\
\hline Mean & 2.56 & 58.70 & 9.46 & 16.17 & 4.97 \\
\hline CV (\%) & 7.83 & 7.57 & 6.23 & 13.11 & 11.31 \\
\hline
\end{tabular}

* Means followed by different lowercase letters in the column differ from each other by the t-test (LSD) at $5 \%$ of significance. 
Table 7. Leaf area (LA), leaf dry mass (LDM), stem dry mass (SDM), shoot dry mass (SHDM), root system dry mass (RSDM) and total dry mass (TDM) of sorghum plants, with different Azospirillum brasilense inoculation methods.

\begin{tabular}{lcccccc}
\hline \multirow{2}{*}{ Treatment } & LA & LDM & SDM & SHDM & RSDM & TDM \\
\cline { 2 - 7 } & $\mathrm{cm}^{2}$ & & & g plant & & \\
\hline Without inoculation & $5.54 \mathrm{a}^{*}$ & $1.92 \mathrm{a}$ & $0.96 \mathrm{a}$ & $2.87 \mathrm{a}$ & $2.65 \mathrm{~b}$ & $5.52 \mathrm{a}$ \\
Seed & $6.38 \mathrm{a}$ & $2.38 \mathrm{a}$ & $1.28 \mathrm{a}$ & $3.65 \mathrm{a}$ & $4.96 \mathrm{a}$ & $8.61 \mathrm{a}$ \\
Sowing furrow & $6.47 \mathrm{a}$ & $2.36 \mathrm{a}$ & $1.20 \mathrm{a}$ & $3.55 \mathrm{a}$ & $3.08 \mathrm{~b}$ & $6.64 \mathrm{a}$ \\
Foliar spray & $5.96 \mathrm{a}$ & $2.17 \mathrm{a}$ & $1.05 \mathrm{a}$ & $3.22 \mathrm{a}$ & $2.31 \mathrm{~b}$ & $5.52 \mathrm{a}$ \\
\hline \multicolumn{1}{c}{ Hybrid } & & & & & \\
1G 282 & $5.78 \mathrm{a}$ & $2.10 \mathrm{a}$ & $1.06 \mathrm{a}$ & $3.16 \mathrm{a}$ & $3.12 \mathrm{a}$ & $6.28 \mathrm{a}$ \\
AG 1090 & $6.38 \mathrm{a}$ & $2.31 \mathrm{a}$ & $1.18 \mathrm{a}$ & $3.48 \mathrm{a}$ & $3.38 \mathrm{a}$ & $6.86 \mathrm{a}$ \\
\hline Mean & 6.08 & 2.21 & 1.12 & 3.32 & 3.25 & 6.57 \\
\hline CV (\%) & 13.38 & 18.33 & 21.38 & 19.21 & 22.28 & 19.27 \\
\hline * Means followed by different lowercase letters in the column differ from each other by the t-test(LSD) at 5\% of significance. & &
\end{tabular}

* Means followed by different lowercase letters in the column differ from each other by the t-test (LSD) at $5 \%$ of significance.

with the $A$. brasilense inoculation in the seed, when compared to the foliar and control applications. The increase in the root system dry mass, when A. brasilense was inoculated via seed, may be related to the production of phytohormones by the inoculated bacteria, resulting in a greater growth of the root system (Steenhoudt \& Vanderleyden 2000).

Bacteria of the Azospirillum genus stimulate the growth of lateral roots, root surface area, root length and density, but the intensity at which the plant expresses these effects varies according to the plant species, cultivar and mainly inoculum concentration (Okon \& Labander-Gonzales 1994). These results occur due to the production of indoleacetic acid by diazotrophic bacteria such as Azospirillum spp. Kolb \& Martin (1985) observed an increase in the number and length of lateral roots of beet inoculated with $A$. brasilense, and there was a correlation with the indoleacetic acid concentration in the bacterial culture medium used for seed inoculation. This set of factors may explain why the seed inoculation promoted an increase in the dry mass of the root system, due to the direct contact of the inoculant with the seed.

In general, the $A$. brasilense inoculation did not result in positive effects for the initial growth of sorghum. A factor that may explain the absence of bacterial effects is the soil $\mathrm{pH}$ (5.2), since, under in vitro conditions, the optimum $\mathrm{pH}$ for the development of Azospirillum spp. is between 6.0 and 6.8 (Cardoso et al. 2010), thus not expressing beneficial effects during the initial growth of the crop. It is also necessary to consider the genetic and functional diversity that the bacteria present, which can result in a variation in their activity according to the concentrations of potassium and nitrogen in the soil, since these elements are involved in the biological fixation of nitrogen and production of plant hormones (Radwan et al. 2005).

Finally, as verified in this study and observed in other researches (Marini et al. 2015, Pereira et al. 2015, Feldmann et al. 2018), A. brasilense has a different performance according to the genotype of the host plant. Therefore, the greatest challenge for the producer to get more profitability with the use of $A$. brasilense is to use the most efficient bacteria, independently of the host genotype.

\section{CONCLUSIONS}

1. The Azospirillum brasilense application to the seed can reduce the emergence percentage and the emergence speed index of corn seedlings, depending on the genotype, but its application does not influence the initial growth of corn plants;

2. The $A$. brasilense inoculation via seed and sowing furrow can reduce the emergence percentage and increase the mean emergence time of sorghum seedlings, depending on the genotype, while its inoculation via seed results in an increase in the dry mass of the root system of sorghum plants.

\section{REFERENCES}

ARAÚJO, R. M. et al. Resposta do milho verde à inoculação com Azospirillum brasilense e níveis de nitrogênio. Ciência Rural, v. 44, n. 9, p. 1556-1560, 2014.

BASHAN, Y.; BASHAN, L. E. Plant growth promoting. In: HILLEL, D. (Ed.). Encyclopedia of soil in the environment. Oxford: Elsevier, 2005. p. 103-115. 
BENINCASA, M. M. P. Análise de crescimento de plantas: noções básicas. Jaboticabal: Funep, 2003.

CARDOSO, I. C. M. et al. Ocorrência de bactérias endofíticas do gênero Azospirillum em arroz irrigado no estado de Santa Catarina. Revista de Ciências Agroveterinárias, v. 9, n. 2, p. 178-186, 2010.

CASSÁN, F. et al. Basic and technological aspects of phytohormone production by microorganisms: Azospirillum sp. as a model of plant growth promoting rhizobacteria. In: MAHESHWARI, D. K. (Ed.). Bacteria in agrobiology: plant nutrient management. Heidelberg: Springer, 2011. p. 141-182.

CICILIATO, A. L.; CASIMIRO, E. L. N. Inoculante Azospirillum brasilense via foliar associado a diferentes fertilizantes foliares na cultura do milho. Revista Cultivando o Saber, v. 8, n. esp., p. 1-10, 2015.

COSTA, R. R. G. F. et al. Efficiency of inoculant with Azospirillum brasilense on the growth and yield of secondharvest corn. Pesquisa Agropecuária Tropical, v. 45, n. 3, p. 304-311, 2015.

DARTORA, J. et al. Adubação nitrogenada associada à inoculação com Azospirillum brasilense e Herbaspirillums eropedicae na cultura do milho. Revista Brasileira de Engenharia Agrícola e Ambiental, v. 17, n. 10, p. 10231029, 2013.

EDMOND, J. B.; DRAPALA, W. J. The effects of temperature, sand and soil, and acetone on germination of okra seed. Proceedings of the American Society for Horticultural Science, v. 71, n. 1, p. 428-434, 1958.

FELDMANN, N. A. et al. Wheat cultivars submitted to seed inoculation with Azospirillum brasilense and nitrogen application in different environments. Cientifica, v. 46, n. 1, p. 95-100, 2018.

GONÇALVES JUNIOR, A. C.; LUCHESE, E. B.; LENZI, E. Avaliação da fitodisponibilidade de cádmio, chumbo e crômio em soja cultivada em Latossolo Vermelho Escuro tratado com fertilizantes comerciais. Química Nova, v. 23, n. 2, p. 173-177, 2000.

GUIMARÃES, S. L. et al. Características produtivas de plantas de milho inoculadas com Azospirillum spp. cultivada em solo do Cerrado. Enciclopédia Biosfera, v. 9, n. 16, p. 558-567, 2013.

HUNGRIA, M. Inoculação com Azospirillum brasilense: inovação em rendimento a baixo custo. Londrina: Embrapa Soja, 2011. (Documentos, 325).

JAMES, E. K.; OLIVARES, F. L. Infection and colonization of sugar cane and other graminaceous plants by endophytic diazotrophs. Critical Review in Plant Science, v. 17, n. 1, p. 77-119, 1998.
KAPPES, C. et al. Inoculação de sementes com bactéria diazotrófica e aplicação de nitrogênio em cobertura e foliar em milho. Semina Ciências Agrárias, v. 34, n. 2, p. 527-538, 2013.

KOLB, W.; MARTIN, P. Response of plant roots to inoculation with Azospirillum brasilense and to application of indole acetic acid. In: KLINGMÜLLER, W. (Ed.). Azospirillum III: genetics, physiology, ecology. Heidelberg: Springer-Verlag, 1985. p. 215-221.

MAGUIRE, J. D. Speed of germination-aid in selection and evaluation for seedling emergence and vigor. Crop Science, v. 2, n. 1, p. 176-177, 1962.

MARINI, D. et al. Growth and yield of corn hybrids in response to association with Azospirillum brasilense and nitrogen fertilization. Revista Ceres, v. 62, n. 1, p. 117123, 2015.

MORAES, G. P. et al. Adubação nitrogenada associada à inoculação com Azospirillum brasilense na cultura do milho. Revista Agropecuária Técnica, v. 38, n. 3, p. 109116, 2017.

MORAIS, T. P. et al. Aspectos morfofisiológicos de plantas de milho e bioquímico do solo em resposta à adubação nitrogenada e à inoculação com Azospirillum brasilense. Revista Ceres, v. 62, n. 6, p. 589-596, 2015.

NOVAKOWISKI, J. H. et al. Efeito residual da adubação nitrogenada e inoculação de Azospirillum brasilense na cultura do milho. Semina Ciências Agrárias, v. 32, suppl., p. 1687-1698, 2011.

NUNES, P. H. M. P. et al. Produtividade do trigo irrigado submetido à aplicação de nitrogênio e à inoculação com Azospirillum brasilense. Revista Brasileira de Ciência do Solo, v. 39, n. 1, p. 174-182, 2015.

OKON, Y.; LABANDER-GONZALES, C. A. Agronomic applications of Azospirillum: an evaluation of 20 years worldwide field inoculation. Soil Biology and Biochemistry, v. 26, n. 12, p. 1591-1601, 1994.

PANDOLFO, C. M. Desempenho de milho inoculado com Azospirillum brasilense associado a doses de nitrogênio em cobertura. Agropecuária Catarinense, v. 27, n. 3, p. 94-99, 2015.

PEREIRA, L. M. et al. Seed quality, chlorophyll content index and leaf nitrogen levels in maize inoculated with Azospirillum brasilense. Revista Ciência Agronômica, v. 46, n. 3, p. 630-637, 2015.

QUADROS, P. D. et al. Desempenho agronômico a campo de híbridos de milho inoculados com Azospirillum. Revista Ceres, v. 61, n. 2, p. 209-218, 2014.

RADWAN, T. E. E.; MOHANMED, Z. K.; REIS, V. M. Aeração e adição de sais na produção de ácido indol 
acético por bactérias diazotróficas. Pesquisa Agropecuária Brasileira, v. 40, n. 10, p. 997-1004, 2005.

REIS JUNIOR, F. B. et al. Inoculação de Azospirillum amazonense em dois genótipos de milho sob diferentes regimes de nitrogênio. Revista Brasileira de Ciência do Solo, v. 32, n. 3, p. 1139-1146, 2008.

REPKE, R. A. et al. Eficiência da Azospirillum brasilense combinada com doses de nitrogênio no desenvolvimento de plantas de milho. Revista Brasileira de Milho e Sorgo, v. 12, n. 3, p. 214-226, 2013.

ROCKENBACH, M. D. A. et al. Eficiência da aplicação de Azospirillum brasilense associado ao nitrogênio na cultura do milho. Acta Iguazu, v. 6, n. 1, p. 33-44, 2017.

SANGOI, L. et al. Desempenho agronômico do milho em razão do tratamento de sementes com Azospirillum sp. e da aplicação de doses de nitrogênio mineral. Revista Brasileira de Ciência do Solo, v. 39, n. 4, p. 1141-1150, 2015.

SKONIESKI, F. R. et al. Effect of seed inoculation with Azospirillum brasilense and nitrogen fertilization rates on maize plant yield and silage quality. Revista Brasileira de Zootecnia, v. 46, n. 9, p. 722-730, 2017.
SOUZA, E. J. et al. Inoculação de Azospirillum brasilense na qualidade fisiológica de sementes de milho doce. Nucleus, v. 11, n. 1, p. 131-140, 2014.

SOUZA, E. M. et al. Does the nitrogen application associated with Azospirillum brasilense inoculation influence corn nutrition and yield? Revista Brasileira de Engenharia Agrícola e Ambiental, v. 23, n. 1, p. 53-59, 2019.

STEENHOUDT, O.; VANDERLEYDEN, J. Azospirillum, a free living nitrogen-fixing bacterium closely associated with grasses: genetic, biochemical and ecological aspects. FEMS Microbiology Ecology, v. 24, n. 4, p. 487-506, 2000.

SZILAGYI-ZECCHIN, V. J.; MARRIEL, I. E.; SILVA, P. R. F. Produtividade de milho inoculado com Azospirillum brasilense em diferentes doses de nitrogênio cultivado em campo no Brasil. Revista de Ciências Agrárias, v. 40, n. 4, p. 795-798, 2017.

UNITED STATES OF AMERICA (USA). Soil Survey Staff. Keys to soil taxonomy. 11. ed. Washington, DC: USDA Natural Resources Conservation Service, 2010.

VOGT, G. A. et al. Desempenho de genótipos de milho na presença ou ausência de inoculação com Azospirillum brasilense e adubação nitrogenada de cobertura. Agropecuária Catarinense, v. 27, n. 2, p. 49-54, 2014. 